\title{
ТЕОРЕТИКО-ФУНКЦЙНЕ ТРАКТУВАННЯ ІМПЕРАТИВА: ПРОБЛЕМИ ВИЗНАЧЕННЯ СТРУКТУРИ Й ОПИСУ
}

\author{
Бортун К. О.
}

\section{ВСТУП}

Граматичні студії, концептуальні засади яких оперті на функційний підхід до аналізу мовних одиниць, створили сприятливі умови для дослідження поняття імперативності в сучасній українській мові. Функційно-семантична категорія імперативності вступає із загальною категорією модальності в складну взаємодію. Імперативні висловлення традиційно й цілком обгрунтовано зараховують до ірреальної модальності, водночас вони виявляють значення повинності й можливості, тобто безпосередньо стосуються й внутрішньосинтаксичної модальності. Очевидний взаємозв'язок категорії імперативності й з такими часто розглядуваними в межах модального комплексу типами значень, як твердження/заперечення, емоиійна та якісна оиінка змісту висловлення й, природно, иільова настанова мовия.

Посилена увага до проблем імператива й імперативності в останні десятиліття зростає. О.В. Бондарко ${ }^{1}$ розробив засади функційносемантичного поля імперативності й імперативної ситуації, В.С. Храковський та Л.О. Бірюлін ${ }^{2} 3$ опертям на теорію мовленнєвих актів сформулювали трирівневе змістове визначення спонукальних висловлень та описали прагматичні чинники, що впливають на семантичну інтерпретацію спонукання. С. Церенчимедійн ${ }^{3}$ Л.О. Сергієвська ${ }^{4}$ i Й. Крекіч ${ }^{5}$ докладно проаналізували спонукальні

1 Бондарко А.В. Структура императивной ситуации (на материале русского языка). Функционально-типологические аспекты анализа императива. Семантика и прагматика повелительных предложений. Москва : Наука, 1990. Ч. 2. 152 с.

2 Бирюлин Л.А., Храковский В.С. Повелительные предложения: проблемы теории. Типология императивных конструкций / под ред. В.С. Храковского. Санкт-Петербург : Наука, 1992. 301 с.

${ }^{3}$ Церенчимедийн С. Речевые акты побуждения, их типы и способы выражения в русском языке : дисс. ... докт. филол. наук : 10.02.01. Москва, 1993. 246 с.

4 Сергиевская Л.А. Императивные предложения со значением совместного действия в современном русском языке : автореф. дисс. ... канд. филол. наук : 10.02.01. Москва, 1982. 20 с.

5 Крекич Й. Пермиссивные побудительные высказывания в русском языке. Szeged. Dissertaciones Slavicae. 1988. № XX. C. 103-111. 
висловлення сучасної російської мови, практично всі дослідники запропонували свої варіанти семантико-прагматичного членування російського масиву спонукальних мовленнєвих актів.

Проте не всі проблеми, пов'язані з поняттям імператива, можна вважати остаточно розв'язаними. Запропонована В.С. Храковським та Л.О. Бірюліним ${ }^{6}$ семантична структура спонукального висловлення не охоплює деяких соціально значущих різновидів спонукання (наприклад, дозволу, пропозиції, запрошення). Не схарактеризований лінгвістичний механізм транспозиції способу на рівні функційносемантичних категорій. Сама множинність варіантів класифікації спонукальних інтерпретацій засвідчує потребу подальшого опрацювання проблематики.

Специфіку відношень між учасниками мовного спілкування та способи їх мовного втілення активно вивчають у сучасній лінгвістиці. Актуальними $€$ дослідження граматичних, семантичних, прагматичних і типологійних особливостей імперативних висловлень, правил їх функціювання в мовленні, у стилістиці (зокрема в публіцистичному й офіційно-діловому стилях).

У мовознавстві дискусійним $є$ питання самого статусу імператива й імперативних висловлень, граматичних одиниць, що належать до їх складу, додаткових аргументів потребують також факти транспозиційного варіювання імперативного значення, пов'язані з імперативною парадигмою, семантикою тощо.

У науковій літературі поняття імператива частково ототожнюють із граматичною категорією способу дієслова, що $є$ однією з найскладніших i малодосліджених в українському мовознавстві, а іiї вивчення належить до актуальних завдань теоретичної морфології та стилістики.

Імперативними ми вважатимемо висловлення, у яких мовець самим фактом свого існування намагається каузувати виконання експліцитно вказаної в цьому висловленні дії, у синтаксичній структурі яких присудок виражений спеціалізованими синтетичними чи аналітичними (iз запереченням або без заперечення) формами імперативної одиниці.

\section{1. Каузація й імперативні висловлення}

Парадигму наказового способу, якому не властива категорія часу, становлять прості (синтетичні) і складні (аналітичні) форми, утворювані від основи теп. часу (для дієслів недоконаного виду)

${ }^{6}$ Храковский В.С. Императив и залог (к вопросу о взаимодействии граммем разных грамматических категорий Функционально-типологические аспекты анализа императива. Москва, 1990. Ч. 1 : Грамматика и типология повелительных предложений / под ред. Л.А. Бирюлина, В.С. Храковского. 152 с. 
і теп.-майб. часу (для дієслів доконаного виду). До простих належать форми другої ос. одн. і першої та другої ос. мн., до складних - форми третьої ос. одн. і мн. ${ }^{7}$ У значеннєвому плані аналітичних форм наказового способу на перший план постає модальність бажання, а не наказу, безпосереднього спонукання до дії.

Що ж до каузації, то іiї ми розуміємо в широкому значенні - як закінчення або запобігання дії або стану, загалом будь-якій зміні. Запропоноване формулювання є визначенням ілокутивної семантики (для якої, слідом за Дж. Серлем ${ }^{8}$, часто використовують також термін «директив»). Висловлення $\epsilon$ імперативним за умови вираження каузації мовцем певної дії. Якщо єдиним або основним значенням деякого показника слугує вказівка на те, що висловлення, яке його містить, $\epsilon$ імперативним, то такий показник логічно номінувати спеціалізованим імперативним. Відповідно до цього, форму або конструкцію, яка містить спеціалізований імперативний показник, називатимемо спеціалізованою імперативною формою. Якщо ж ця форма утворена від дієслівної основи, вона $є$ спеціалізованою імперативною формою дієслова.

Надалі будемо називати імперативними як форми, так і речення, уважаючи, що з контексту зрозуміло, про що саме йдеться. Визначення імператива, засноване на понятті каузації, заперечено, зокрема, у працях Е. Дейвіс, оскільки, на іiі думку, воно не пояснює такі вживання імператива, як дозвіл і пораду'. Це заперечення, однак, можна нейтралізувати, якщо врахувати, що каузація в імперативі (як і каузація загалом) може мати два різновиди - фактитивну та пермісивну (див. про це в праці ${ }^{10}$ ).

Хоч В.П. Недялков і Г.Г. Сильницький пояснюють відмінність між фактитивною та пермісивною каузацією тільки на прикладах, уважаємо, що ऑiі можна сформулювати більш експліцитно, скориставшись «трансцендентальним принципом причинності» 3. Вендлера. Дослідник, зокрема, наголошує, що для кожної події існує набір фактів, кожен із яких $є$ необхідною умовою реалізації цієї події, а вся сукупність формує достатню умову ії реалізації ${ }^{11}$. Інакше кажучи,

${ }^{7}$ Безпояско О.К. Граматика української мови : морфологія. Київ : Либідь, 1993. C. 374.

${ }^{8}$ Searle J.R. A taxonomy of illocutionary acts. Expression and Meaning. Cambridge etc. : Cambridge University Press, 1979. C. 13-14.

${ }^{9}$ Davies E. The English Imperative. London et al. : Croom Helm, 1986. P. 39-40.

${ }^{10}$ Недялков В.П., Сильницкий Г.Г. Типология морфологических и лексических каузативов. Типология каузативных конструкичй: Морфологический каузатив / за ред. А.А. Холодовича. Ленинград : Наука, 1969. С. 28.

11 Вендлер. 3. Причинные отношения. Новое в зарубежной лингвистике. Вып. 18. Москва, 1986. С. 276. 
дія буде зреалізована, якщо дотримуватися всіх умов, що визначають цю множинність. Фактитивна каузація деякої дії $\mathrm{P}$ передбачає виконання достатньої умови для $\mathrm{P}$, тобто (за термінологією вендлерівської безлічі) або відразу всіх умов, що належать до цієї множинності, або тих із них, які ще не реалізовані. Навпаки, пермісивні каузації охоплюють учинення необхідної умови, тобто тільки однієї з умов, що входять у цю множиність. Передбачено також, що недостатню умову суб'єкт дії Р виконає сам.

Найчастіше невиконаною умовою $є$ виявлювана воля (бажання) суб'єктів здійснити дію; звідси, мабуть, і термін «пермісивна каузація». Однак це необов'язково: суб'єктом Р може бути й неживий предмет.

Надалі не раз будемо акцентувати на важливості самого поняття каузації, так само як і iі різновидів, для різних аспектів семантики та функціювання імператива. Перед нами якраз один із таких випадків, де протиставлення дозволу і поради, з одного боку, і наказу й прохання з іншого, відображає відмінність між пермісивною та фактитивною каузацією. Усі ці випадки повністю враховані в наведеній дефініції імператива.

Імперативу як одному 3 різновидів каузатива - перформативному каузативу - присвячені статті В.Б. Касевич ${ }^{12}$, Ю.А. Левицького ${ }^{13}$. Безпосередньо на розширенні можливих типів каузації грунтоване вживання імперативних форм зі значенням повинності в конструкціях мети. До того ж варто згадати ще про одне розмежування типів каузації (незалежно від її поділу на фактитивну й пермісивну). Каузацію поділяють на пряму й опосередковану. За умови, що одна подія $\left(\mathrm{P}_{1}\right)$ спричинила іншу $\left(\mathrm{P}_{2}\right)$, ідеться про пряму каузацію. Якщо ж подія $\mathrm{P}_{1}$ каузує іншу подію $\mathrm{P}_{3}$, яка, зі свого боку, каузує $\mathrm{P}_{2}$, уважатимемо, що $\mathrm{P}_{1}$ каузує $\mathrm{P}_{2}$ опосередковано. Надалі називатимемо подію або дію $\mathrm{P}_{3}$ «проміжною дією» і позначатимемо ii як $\mathrm{P}_{\text {aux }}$. Безперечно, проміжних подій може бути цілий ланцюг, у якому кожна попередня подія спричиняє наступну.

\section{2. Теоретичні проблеми категорії імперативності в сучасній лінгвістиці: дефініції визначення}

У лінгвістиці наявна низка дефініцій імператива ${ }^{14}$, у формулюванні яких автори або прагнуть знайти універсальне значення, що об'єднує як

12 Касевич В.Б. Императивность, каузативность, перформативность. Функционально-типологические аспекты анализа императива. Москва : АН СССР : Ин-т языкознания, 1990. Ч. 2. 152 с.

13 Левицкий Ю.А. Лингвистика текста. Москва : Высшая школа, 2006. 207 с.

${ }^{14}$ Гусев В.Ю. Типология специализированных глагольных форм императива : дисс. ... канд. филол. наук : 10.02.20. Москва, 2005. 296 с. 
прямі, так і непрямі вживання імперативних форм ${ }^{15}$, або відкидають непрямі репрезентації, у яких не виражено безпосереднє звернення мовця до адресата зі спонуканням до дії, і враховують виключно пряме, категорійне значення імператива ${ }^{16}$. Наведені нижче дефініції імператива й імперативності, на які спиратимемося в подальшому описі, базовані на іншому, вужчому, підході, за якого взято імперативні форми в їх прямому значенні, а форми, що не мають імперативної семантики, не враховано. Формулювання інваріантного значення імператива, засновані на пошукові спільних семантичних ознак у всіх його вживаннях, $\epsilon$ не зовсім переконливим ${ }^{17}$.

Як зазначає О.В. Бондарко, «з основними формами імператива їх поєднують такі ознаки, як значення спонукання, імперативна інтонація. Однак ці форми відрізняються від основних неповною парадигматичністю, недостатністю формальної характеристики, обмеженістю охоплення лексики, стилістичними обмеженнями, особливим ставленням до особи, не характерної для основних форм імператива» ${ }^{18}$.

Згідно 3 «Русской грамматикой» (1980) (РГ 1980) ${ }^{19}$, «значення спонукання, тобто репрезентація дії як необхідної, до якої спонукає кого-небудь мовець» ${ }^{20}, \epsilon$ категорійним значенням наказового способу. У наказовому способі протиставлені два ряди форм: 1) основні форми 2-ї ос. (одн. і мн.): візьми, говори, візьміть, говоріть, що утворюють ядро парадигми; 2) ряд форм спільної дії: візьмімо, будемо говорити. Форми спільної дії витлумачені як форми множини, що позначають спонукання, яке стосується двох або більше осіб: до адресата (або до групи осіб, що постають як адресат) і до самого мовця ${ }^{21}$.

Сьогодні традиційне зарахування імператива до низки непрямих дієслівних форм способу переглянуто. Розробляючи питання про співвідношення імператива й дієслівного способу, сучасні лінгвісти, зокрема Л.С. Срмолаєва ${ }^{22}$ Д.А. Штелінг ${ }^{23}$, Р.В. Пазухін ${ }^{24}$,

15 Пешковский А.М. Русский синтаксис в научном освещении Звегинцева В.А. История языкознания XIX - XX веков. Москва, 1965. Ч. 2. С. 221-244.

${ }^{16}$ Ebeling C.L. On the verbal predicate in Russian. The Hague, 1956. 212 p.

17 Крекич Й. Пермиссивные побудительные высказывания в русском языке. Szeged. Dissertaciones Slavicae. 1988. № XX. С. 109.

${ }^{18}$ Бондарко А.В. Структура императивной ситуации (на материале русского языка). Функционально-типологические аспекты анализа императива. Семантика и прагматика повелительных предложений. Москва : Наука, 1990. Ч. 2. С. 4-9.

${ }^{19}$ Русская грамматика / Акад. наук СССР, Ин-т рус. яз. ; редкол. : докт. филол. наук Н.Ю. Шведова (гл. ред.) и др. Москва : Наука, 1980. Т. 1. 620 с.

${ }^{20}$ Так само. С. 620.

${ }^{21}$ Так само. С. 620 .

22 Ермолаева Л.С. Типология системы наклонений в современных германских языках. Вопросы языкознания. 1977. № 4. С. 96-106. 
В.С. Храковський та О.П. Володін ${ }^{25}$, висновують, що, 3 огляду на свої формальні (відмінні від індикатива власні показники, інша структурна організація парадигми) i семантичні особливості (наявність додаткового предиката волевиявлення, унаслідок чого імператив може бути схарактеризований як рамкова конструкція), а також специфічні комунікативні (апелятивні) функції, імператив не входить до складу категорії дієслівного способу. Оскільки категорія імперативності не $\epsilon$ способом, то вона не пов'язана з вираженням реальності/нереальності повідомлюваного факту й загалом не має дескриптивного значення, яке могло б бути схарактеризоване як реальне або нереальне.

Найбільш універсальне й узагальнене значення імператива сформульовано в роботі Л.О. Бірюліна та В.С. Храковського: «Наказовими можна називати стверджувальні/заперечні речення, у яких виражена ідея прямої мовної каузації інтерпретована як: (не) бажаючи виконання дії Р, яку в момент мовлення $\mathrm{t}$ або не виконує, або виконує, мовець повідомляє слухачеві, хто (не) повинен бути агенсом дії $\mathrm{P}$, і намагається каузувати (не) виконання дії $\mathrm{P}$ самим фактом цього повідомлення» ${ }^{26}$.

Зупинимося докладніше на співвідношенні локутивного й ілокутивного планів, тобто на кореляції ролей учасників імперативної ситуації й учасників комунікативного акту. На відповідності й невідповідності учасників названих планів Л.О. Бірюлін ${ }^{27}$ вибудовує класифікацію імперативних висловлень, що охоплює чотири логічно можливі пункти:

1) Мовець $=$ Прескриптор, Слухач $=$ Виконавець;

2) Мовець $=$ Прескриптор, Слухач $\neq$ Виконавець;

3) Мовець $\neq$ Прескриптор, Слухач = Виконавець;

4) Мовець $\neq$ Прескриптор, Слухач $\neq$ Виконавець.

Перший і другий різновиди можуть породжувати сумніви лише в прихильників вузького погляду на імператив, які заперечують імперативність форм спільної дії (1-а ос. мн.) і форм на зразок нехай співають (3-я ос. одн., мн.), коли виконавцем є особа, яка не бере участі в комунікативному акті, а адресат відіграє роль транслятора.

23 Штелинг Д.А. О грамматическом статусе повелительного наклонения. Известия АН СССР. Серия литературы и языка. 1982. Т. 41. № 3. С. 266-271.

${ }^{24}$ Пазухин Р.В. Так называемое «повелительное наклонение» и его парадигма. Studia Rossica Posnaniensia. Posnan. 1974. № 6. C. 85-95.

${ }^{25}$ Храковский В.С., Володин А.П. Семантика и типология императива. Русский императив. Москва : Едиториал УРСС, 2002. 272 с.

${ }^{26}$ Бирюлин Л.А. Семантика и прагматика русского императива. Helsinki : Slavica Helsingiensia, 1994. C. 7.

27 Так само. 
Випадки, коли мовець не є прескриптором, уважаємо такими, що заслуговують на увагу.

Третій тип мовець $\neq$ прескриптор, слухач = виконавець характерний лише для прямої мови, коли мовець $є$ транслятором, а прескриптор не бере участі в комунікації: Джеррі просив передати: «Бережи сина»мовець $=$ транслятор, Джеррі $=$ прескриптор, який не бере участі в комунікації, адресат = виконавець.

Четвертий тип мовець $\neq$ прескриптор, слухач $\neq$ виконавець також трапляється в прямій мові: Майку Джеррі просив передати: «Бережи сина» - мовець $=$ транслятор, Джеррі (3-я ос.) = прескриптор, який не бере участі в комунікації, адресат $\neq$ виконавець.

Надійшов наказ благовірної: «Розморозь холодильник!» - Ну, і як ие зробити? - мовець $=$ транслятор $=$ виконавець, благовірна $(3-я$ ос.) $=$ прескриптор, який не бере участі в комунікації, адресат $\neq$ виконавець.

У цих ситуаціях мовець цитує чужу прескрипцію. Ізольовано від мовлення мовця аналізовані імперативні висловлення є типовими.

Такі випадки, нехай і найчастотніші, можуть бути виокремлені в самостійні типи імперативних висловлень. Але якщо мовець саме в такий спосіб, а не за допомогою підрядної частини бажає висловити прескрипцію, то він просто розігрує роль прескриптора чи ототожнює себе 3 ним. 3 іншого боку, прескриптор як ілокутивна роль має двох референтів: автора прескрипції й автора висловлення.

$€$ ще один випадок, коли прескриптор не збігається з мовцем, - це випадок нереферентного прескриптора у висловленнях на зразок: Усім встати! Суд іде. Приймати один раз на день натщесерие.

Подібні випадки треба відрізняти від «гномічного імператива», зокрема, у пареміях, напр.: Скільки вовка не годуй, він все в ліс дивиться. На чужсий коровай рота не роззявляй.

Подібні універсальні висловлення з нереферентними прескриптором і виконавцем уже не є імперативними в прямому розумінні слова, а названі імперативними лиш умовно, оскільки в них утрачені основні ознаки імперативності, про які йдеться нижче.

Так само не є імперативними й речення, наведені Л.О. Бірюліним ${ }^{28}$ як приклади четвертого різновиду: Все ушли, а я дома сиди и работай! Они там револючию устроили, а мы жри обезьян!

Л.О. Бірюлін ${ }^{29}$ схильний бачити в подібних структурах імперативні висловлення з акцентованим значенням повинності, хоч і зазначає, що вони $є$ перехідним типом до імперативів із нестандартною семантикою. Разом 3 імперативом як граматикалізованим засобом вираження

${ }^{28}$ Бирюлин Л.А. Семантика и прагматика русского императива. Helsinki : Slavica Helsingiensia, 1994. $229 \mathrm{c}$.

29 Так само. 
спонукання в науковій літературі фіксують також гортатив (спонукання до спільної дії), юсив (непряме спонукання, спонукання 3-ї ос.), прохібітив (заперечне спонукання, заборона дії), адмонітив (застереження щодо можливих негативних наслідків планованої діï). Нам імпонує «розширене» розуміння імператива, найбільш повно представлене в концепції В.С. Храковського й О.П. Володіна ${ }^{30}$.

Поняття «імперативність» нерідко вживають як інтуїтивно зрозуміле. У дефініціях трапляються не лише перерахування часткових значень (наказ, прохання, благання), а й гранично узагальнені, розмиті формулювання (на зразок «наявність імпульсу до вчинення дії»).

У праці А.І. Ізотова виокремлено категорійну (пряму) (імперативна семантика виражена специфічними граматичними (морфологічними та синтаксичними) формами) і некатегорійну (непряму) імперативність (імперативну семантику передають невласне імперативними способами $)^{31}$.

Некатегорійну імперативність диференціюють на експліцитну (імперативна семантика виражена через запитання, оптативність або майбутній час індикатива) та імпліцитну (імперативну семантику передає пропозитивний зміст висловлення). Однак, на наш погляд, досить складно об'єднати в одну категорію висловлення на зразок: Купіть хліба! (категорійна імперативність); Чи не могли б ви купити хліба? (експліцитно некатегорійна імперативність); Ми хочемо хліба! (імпліцитно некатегорійна імперативність).

У всіх трьох наведених висловленнях можна виокремити загальну семантичну частину - спонукальність (директивність) і бажаність, а також загальну ілокутивну мету - вплив на поведінку адресата. Але, на нашу думку, цих двох умов недостатньо, щоб визначити всі три висловлення як імперативні.

Що ж до питання категорійності імператива, то ми вважаємо, що категоричність висловлення повинні вивчатися у двох взаємопов'язаних аспектах - семантичному та прагматичному: семантика категоричності орієнтована на виявлення мовних знаків, що сприяють підвищенню або зниженню категоричності судження; прагматика - на визначення й опис тих ситуативних чинників, що зумовлюють ступінь категоричності висловлення ${ }^{32}$.

${ }^{30}$ Храковский В.С., Володин А.П. Семантика и типология императива. Русский императив. Москва : Едиториал УРСС, 2002. 272 с.

31 Изотов А.И. Императивность как прагмалингвистический феномен: На материале чешского языка. Москва : Едиториал УРСС, 2008. С. 13-14.

32 Бортун К.О. Імперативність і категоричність у структурі висловлення: основні підходи до аналізу. Науковий вісник Міжнародного гуманітарного університету. Серія «Філологія» : збірник наукових праць. 2016. Вип. 20. С. 16. 


\section{3. Семантичні складники імператива \\ та поняття «імперативна ситуація»}

О.В. Бондарко розробив поняття імперативної ситуації ${ }^{33}$, а Л.О. Бірюлін - багатопланову модель структури змісту імперативних висловлень ${ }^{34}$. Спираючись на їхні роботи й дослідження В.Ю. Гусєва ${ }^{35}$ i В.Б. Касевич ${ }^{36}$, імперативність витлумачуємо як сукупність деяких обов'язкових значень, які вможливлюють виокремити імперативні висловлення з-поміж інших, а також сформулювати специфіку семантики імператива. Однією з умов імперативності $є$ значення каузального впливу. Уживання імперативної форми (морфологічної або синтаксичної) - це граматичний спосіб висловити значення каузації. Форма імператива на зразок купи, купіть позначає «каузує дію, названу основою, для того чи того виконавця» (особа й число імператива $\epsilon$ семантичними, а не узгоджувальними категоріями). Відмінність від морфологічного каузатива полягає в тому, що в імперативі збігається план змісту й план вираження - дія не названа (ти його смішиш - каузує сміятися), а проголошення і є дія (Розсміши його - я тебе каузую змусити його сміятися). Це зближує імперативні висловлення 3 перформативними. Перформативність на лексичному рівні виражена особливими лексемами, проголошення яких реалізує ситуацію (клянусь, проголошую). На граматичному рівні перформативність представлена імперативними формами, висловлення з імперативом $€$ дією - каузальним впливом на адресата. Контрольованість, під якою зазвичай розуміють залежність/незалежність ситуації від волі суб'єкта (тобто агентивності суб'єкта), є ще одним необхідним компонентом імперативності ${ }^{37}$.

Щоб визначити категорії імперативності, потрібно описати семантичні складники імперативності (а не функційні підтипи чи способи вираження), до яких зараховано: 1) каузативність; 2) перформативність; 3) контрольованість. Без цих характерних ознак не може бути описане імперативне речення, навіть якщо воно містить дієслівну імперативну форму.

33 Бондарко А.В. Структура императивной ситуации (на материале русского языка). Функционально-типологические аспекты анализа императива. Семантика и прагматика повелительных предложений. Москва : Наука, 1990. Ч. 2. С. 80.

${ }^{34}$ Бирюлин Л.А. Семантика и прагматика русского императива. Helsinki : Slavica Helsingiensia, 1994. $229 \mathrm{c}$.

35 Гусев В.Ю. Типология специализированных глагольных форм императива : дисс. ... канд. филол. наук : 10.02.20. Москва, 2005. 296 с.

36 Касевич В.Б. Императивность, каузативность, перформативность. Функционально-типологические аспекты анализа императива. Москва : АН СССР: Ин-т языкознания, 1990. Ч. 2. 152 с.

${ }^{37}$ Гусев В.Ю. Типология специализированных глагольных форм императива : дисс. ... канд. филол. наук : 10.02.20. Москва, 2005. 296 с. 
Досить часто імперативність визначають через спонукання, яке кваліфікують як мету імперативного речення або як ситуацію, що $\epsilon$ основою імператива. Іноді спонукальність (директивність) та імперативність трактують як синонімічні поняття. Категорію спонукання визначаємо як більш загальну й абстрактну категорію.

Презумпція спонукання охоплює чотири типи умов:

1) цей акт тлумачать як спробу впливу особи (прескриптора) домогтися того, щоб особа, яка впливає (виконавець), виконала щось;

2) прескриптор хоче, щоб виконавець зробив щось;

3) момент часу вчинення дії виконавцем повинен відбуватися пізніше за момент часу проголошення спонукання;

4) наявні попередні умови:

a) виконавець у змозі виконати щось;

б) прескриптор уважає, що виконавець спроможний зробити щось;

в) виконавець навряд чи зробить це 3 власної волі за нормального перебігу подій;

г) стан, який $\epsilon$ результатом дії, не $€$ обов'язковим семантичним компонентом імперативності.

На нашу думку, замість бажаності доречніше говорити про значення повинності. Каузована ситуація видається мовцеві можливою, але необов'язково бажаною. Так само виконавець не завжди бажає виконувати прескрипцію, але найчастіше змушений це робити.

Засоби вираження імперативності не обмежені морфологічними формами наказового способу. Наприклад, імперативність може бути виражена за допомогою індикатива: Береш швабру $i$ драєш підлогу! А ну швидко взяв швабру! Ці висловлення відповідають умовам імперативності: каузація, перформативність, відсутність пропозиції й асерція. Єдина відмінність цих форм від власне імперативних 3 афіксом - $u-$ - у додатковому емоційному забарвленні та в меншій частоті вживання. У прикладах Відходимо! і Пімли дими! (у значенні Установіть димову завісу) додаткове значення емоційності не марковане, воно характерне для специфічної мовної ситуації, яка покладена в основу функційно-семантичного мікрополя наказу, проте воно повністю відповідає вимогам категорії імперативності. Те саме стосується інфінітива (Стояти! Лежати! Посилити нагляд!) і недієслівних форм імператива (Кругом! У багнети! Відхід двісті! Сапери на трунт!). Ці та наведені вище приклади передають імперативну семантику засобами інших граматичних категорій, їх можна вважати некатегорійними репрезентантами об'єктивації імперативності. Однак немає ніякої необхідності зараховувати до імперативних висловлення на зразок: Вам би підсилити спостереження! Чи не приєднаєте ви багнети? 
Очевидно, деякі імперативи зазнають переформулювання відповідно до вимог категорії ввічливості (але при цьому вони втрачають категоричність): Передайте сіль! - Чи не передасте сіль? Водночас в інших одиницях не спостерігаємо подібних трансформацій (оскільки є загроза втрати змісту та розуміння ситуаціі); імператив Лягай! у ввічливій формі Чи не ляжете ви? викличе комічний ефект, а не каузацію необхідної ситуації.

Якщо проблема наведених вище непрямих мовленнєвих актів не викликає такого, то фраза Ми хочемо їсти в контексті може мати значення Дайте нам їсти, але так само Дайте нам їсти може передбачати $M и$ хочемо їсти, і питання про те, яке ж значення первинне та чому цей приклад ілюструє категорію імперативності, а не оптативності, залишається відкритим. Не кожне імперативне висловлення має на увазі бажаність каузованої дії (Починайте поліглю̈̈н $\neq$ Я хочу, щоб ви почали капати поліглюён), а бажаність дії (Перекурити б!) не завжди безпосередньо пов'язана з каузацією.

Загалом відзначимо, що в будь-якій мові наявні кілька типових способів вираження спонукання, зокрема й непрямі мовні акти, сутність яких полягає в тому, щоб зняти категоричність, притаманну імперативності, але досягти максимально схожого перлокутивного ефекту, тобто виконання бажаної дії. Основною умовою ввічливості $\epsilon$ усунення категоричності й надання адресатові (виконавцю) свободи вибору (іноді уявної). Ситуації прохання (Купи хліба!), поради (Прийми ліки!) і запрошення (Приходь до нас в гості!) є окремими різновидами директивних мовленнєвих актів і часто розглядувані як окремі випадки категорії імперативності. У таких мовних ситуаціях можливе використання імператива, проте подібні ситуації й утворені ними функційно-семантичні мікрополя керовані дискурсивною категорією ввічливості. У цих трьох мовних ситуаціях адресант може вибрати мовну стратегію - ввічливу або категоричну, і вибір зазвичай залежить від екстралінгвальних чинників. Якщо мовець зупиняється на ввічливій стратегії (Ти не купиш хліба? Прийняв би ти ліки!; Тобі краще прийняти ліки!; Ви б хотіли прийти до нас у гості?), то він автоматично використовує питальну форму (часто із запереченням), умовний спосіб, іноді додаткові формули ввічливості (Чи не будете ви такі люб'язні передати сіль?), а ситуація часто переоріснтована 3 адресата на мовця (покажіть документи - дозвольте поглянути на ваші документи; поверніть книгу - чи можу я отримати книгу назад? дайте ваш телефонний номер - чи не міг би я записати ваш 
телефонний номер? $)^{38}$. Категорія ввічливості також вимагає нівелювати контроль мовця, і цим вона прямо суперечить категорії імперативності. Категорія ввічливості передбачає вживання оптатива, для якого характерна відсутність контролю (на противагу імперативу).

У ввічливій стратегії спостерігаємо розрив між наміром мовця та формою його висловлення. Очевидно, що подібна стратегія не може бути застосована до всіх директивних висловлень, у низці ситуацій вона недоречна (Готуйте операиійне поле!), інколи - факультативна (Пред'явіть документи!), в окремих випадках - обов'язкова або вкрай бажана (Ви не могли б повторити домашнє завдання?). Загалом же в контекстах їі використання зазнає нівеляції імперативність. Не будь-яке директивне висловлення $є$ імперативним, імперативні висловлення - це підклас директивних, незважаючи на те що в них загальна інтенція, імперативні речення мають специфічну форму вираження й специфічну семантичну організацію.

3 іншого боку, постають запитання, які теж іноді зараховують до засобів репрезентації імперативності, - це конструкції на зразок Що я повинен робити? Коли мені приходити? Хто повинен прийти? тощо.

Погоджуємося, що наявні «спонукальні питання» (як існує керування діями адресата, так само наявний i запит на подібне керування), а також те, що в подібних запитаннях уживають морфологічні форми імператива. Проблема лише в тому, чи збережена при цьому імперативна семантика, чи вона втрачена, як, наприклад, у так званому «поступливому імперативі» (Що не кажіть, а важка наша письменницька праия!), «умовному імперативі» (Як ти не крути, але мені не пара), «драматичному імперативі» (Їй прийшла шалена думка випровадити негідника, а він візьми і стукни ї̈ по голові), «Гномічному імперативі» (На чужий коровай очей не поривай). Отже, імперативні запитання $\epsilon$, на нашу думку, ще однією спробою «осягнути неосяжне», тобто об'єднати всі випадки вживання морфологічної форми імператива загальним значенням. Можливо, було б доцільніше вважати, що в низці випадків імперативна семантика втрачена й замінена іншими значеннями.

\section{ВИСНОВКИ}

Отже, у роботі окреслені основні теоретичні аспекти дослідження терміна «імператив», його статус у сучасній лінгвістиці, означені диференційні ознаки імператива, розглянуті наявні в сучасному лінгвістичному дискурсі особливості потрактування імперативних

38 Ларина Т.В. Категория вежливости и стиль коммуникации: сопоставление английских и русских лингвокультурных традиций. Москва : Языки славянских культур, 2009. С. 112. 
речень та імперативних конструкцій, окреслено методологію дослідження.

Зазначимо, що вивчення імператива в конкретних комунікативних ситуаціях, де його використовують мовці 3 тією чи іншою метою, адресуючи конкретним слухачам, не означає, що проблема статусу імператива як елемента мовної системи вже розв'язана, а тому не заслуговує на увагу. Вона сприяє поглибленню уявлень про семантику імператива, що визначає закономірності його вживання, а також певною мірою допомагає виявити нові особливості його плану змісту й формальних засобів.

Дослідження специфіки імператива в українській мові дає нам можливість розглянути його закономірності функціонування в структурі висловлення, адже саме в процесі спілкування в мовця відповідно до комунікативних завдань i 3 метою впливу на співрозмовника (співрозмовників) виникає потреба у висловленнях, у яких частини пов'язані між собою складними семантичними відношеннями.

Аналіз лексико-граматичних засобів репрезентації імперативності в українській мові засвідчив, що вони численні й різноманітні. Значення імперативного висловлення прозоре: мовець фактом свого висловлення намагається каузувати вчинення певної дії. 3 огляду на це, імператив постає різновидом каузатива (перформативним каузативом), із чим пов’язана більшість особливостей його семантики.

Неодмінною умовою успішності імперативного висловлення повинен бути, по-перше, контроль виконавця над дією i, по-друге, контроль мовця над виконавцем. А тому, даючи наказ, мовець повинен думати, що обидва ці різновиду контролю наявні в ситуації, тоді як бажання мовця не $є$ необхідною умовою наказового висловлення.

Імператив - це мовна підсистема зі своєрідною парадигмою форм, лексико-стилістичними властивостями їі елементів, що має специфічну функційну спрямованість. Загалом підсумуємо, що семантика імператива - це значення спонукання, яке полягає в тому, що мовець адресує свою волю співрозмовникові з метою спричинити дію.

\section{АНОТАЦІЯ}

У процесі спілкування в мовця відповідно до комунікативних завдань і з метою впливу на співрозмовника (співрозмовників) виникає потреба у висловленнях, у яких частини пов'язані між собою складними семантичними відношеннями. Саме тому комунікант використовує імперативні висловлення та конструкції для орієнтації на позитивну результативність акту волевиявлення. Так, структури можуть реалізуватися щодо різних адресатів і повинні виконувати (виконати) приписувані їм дії одночасно чи послідовно або ж передбачати різні дії спонукання, протиставлені одна одній. 
Саме тому в роботі проаналізовано теоретичні та методологійні засади вивчення імперативних висловлень, його статус у сучасній лінгвістиці, методологію дослідження. Зокрема ми розкрили способи такої дії, алгоритм передачі значення волевиявлення, основним засобом вираження якого слугують імперативні речення, за своєю семантикою тісно пов'язані 3 комунікативною ситуацією й учасниками мовленнєвого акту.

\section{ЛІТЕРАТУРА}

1. Аксаков К.С. Опыт русской грамматики. Имя. Москва : Либроком, 2011.232 с.

2. Безпояско О.К. Граматика української мови: Морфологія. Київ : Либідь, 1993. 336 с.

3. Беляева Е.И. Грамматика и прагматика побуждения: английский язык. Воронеж : Изд-во Воронежск. ун-та, 1992. 180 с.

4. Бережан Л.В. Категорія спонукальності в сучасній українській мові : дис. ... канд. філол. наук : 10.02.01. Чернівці, 1996. 194 с.

5. Бирюлин Л.А. Семантика и прагматика русского императива. Helsinki : Slavica Helsingiensia, 1994. 229 c.

6. Бирюлин Л.А., Храковский В.С. Повелительные предложения: проблемы теории. Типология императивных конструкций / под ред. В.С. Храковского. Санкт-Петербург : Наука, 1992. 301 с.

7. Бондарко А.В. Структура императивной ситуации (на материале русского языка). Функционально-типологические аспекты анализа императива Семантика и прагматика повелительных предложений. Москва : Наука, 1990. Ч. 2. 152 с.

8. Бортун К.О. Імперативність і категоричність у структурі висловлення: основні підходи до аналізу. Науковий вісник Міжнародного гуманітарного університету. Серія «Філологія» : збірник наукових праць. 2016. Вип. 20. С. 14-17.

9. Бортун К.О. Категорії імператива в сучасній українській мові. Studia Philologica (Філологічні студіi) : збірник наукових праць / Київ. ун-т ім. Бориса Грінченка, 2017. Вип. 9. С. 60-66.

10.Бортун К.О. Структурно-семантичні типи та функції імперативних висловлень у публіцистичному i офіційно-діловому стилях : дис. ... канд. філол. наук : 10.02.01. Черкаси, 2019. 20 с.

11. Буслаев Ф.И. Историческая грамматика русского языка. Москва : Учпедгиз, 1959. $623 \mathrm{c.}$

12. Вендлер 3. Причинные отношения. Новое в зарубежной лингвистике. Вып. 18. Москва, 1986. 392 с.

13. Виноградов В.В. Стилистика. Теория поэтической речи. Поэтика. Москва : Изд-во АН СССР, 1963. 256 с.

14. Вихованець І.Р. Модальність. Українська мова. Енциклопедія / редкол. : В.М. Русанівський, О.О. Тараненко (співголови), М.П. Зяблюк 
та ін. 3-є вид., зі змінами і доп. Київ : Укр. енцикл. ім. М.П. Бажана, 2007. $856 \mathrm{c}$.

15. Вихованець І.Р., Городенська К.Г. Теоретична морфологія української мови: Академічна граматика української мови / за ред. I.P. Вихованця. Київ : Пульсари, 2004. 400 с.

16. Вихованець І.Р., Городенська К.Г. Теоретична морфологія української мови: Академічна граматика української мови / за ред. I.P. Вихованця. Київ : Пульсари, 2004. 400 с.

17. Горпинич В.О. Сучасна українська літературна мова. Морфеміка. Словотвір. Морфонологія. Київ : Вища школа, 1999. 207 с.

18. Грабье В. Семантика русского императива. Сопоставительное изучение русского языка с чешским языком и другими славянскими языками / под ред. А.Г. Широковой и В. Грабье. Москва : Изд-во Моск. ун-та, 1983. 309 с.

19. Граматика сучасної української літературної мови. Морфологія / за ред. К.Г. Городенської. Київ : Видавничий дім Дмитра Бураго, 2017. $752 \mathrm{c}$.

20. Гусев В.Ю. Типология специализированных глагольных форм императива : дисс. ... канд. филол. наук : 10.02.20. Москва, 2005. 296 с.

21. Даскалюк О.Л. Семантико-граматична характеристика імператива сучасної української мови : автореф. дис. ... канд. філол. наук : 10.02.01. Чернівці, 2005. 19 с.

22. Ермолаева Л.С. Типология системы наклонений в современных германских язиках. Вопросы языкознания. 1977. № 4. С. 96-106.

23. Жовтобрюх М.А. Українська літературна мова. Київ : Наук. думка, 1984. 296 с.

24. Загнітко А.П. Теоретична граматика сучасної української мови. Морфологія. Синтаксис. Донецьк : ТОВ «ВКФ «БАО», 2011.992 с.

25. Изотов А.И. Императивность как прагмалингвистический феномен: На материале чешского языка. Москва : Едиториал УРСС, 2008. C. $13-14$.

26. Каранська М.У. Синтаксис сучасної української літературної мови : навчальний посібник. Київ : Либідь, 1995. 312 с.

27. Касевич В.Б. Императивность, каузативность, перформативность. Функционально-типологические аспекты анализа императива. Москва : АН СССР: Ин-т языкознания, 1990. Ч. 2. 152 с.

28. Князев Ю.П. Грамматическая семантика: Русский язык в типологической перспективе. Москва : Языки славянской культуры, $2007.704 \mathrm{c}$.

29. Козьмин О.Г. Интонация побудительных предложений в современном немецком языке. Mатериаль коллоквиума по экспериментальной фонетике и психологии речи. Москва : Изд-во МГУ, 1966. С. 289-315. 
30. Крекич Й. Пермиссивные побудительные высказывания в русском языке. Szeged. Dissertaciones Slavicae. 1988. № XX. С. 103-111.

31.Ларина Т.В. Категория вежливости и стиль коммуникации: сопоставление английских и русских лингвокультурных традиций. Москва : Языки славянских культур, 2009. 512 с.

32. Левицкий Ю.А. Лингвистика текста. Москва : Высшая школа, 2006. $207 \mathrm{c}$.

33. Мельничук О.С. Розвиток структури слов'янського речення. Київ : Наук. думка, 1966. 324 с.

34. Нарушевич-Васильєва О.В. Категорія спонукальності у прагмастилістичному аспекті : автореф. дис. ... канд. філол. наук : 10.02.01. Одеса, 2002. 22 с.

35. Недялков В.П., Сильницкий Г.Г. Типология морфологических и лексических каузативов. Типология каузативных конструкиий: Морфологический каузатив / за ред. А.А. Холодовича. Ленинград : Наука, 1969. С. 20-50.

36. Остин Дж.Л. Слово как действие / пер. с англ. А.А. Медниковой. Новое в зарубежной лингвистике. Вып. 17 : Теория речевых актов / под. общ. ред. Б.Ю. Городецкого. Москва : Прогресс, 1986. С. 22-29.

37. Пазухин Р.В. Так называемое «повелительное наклонение» и его парадигма. Studia Rossica Posnaniensia. Posnan. 1974. № 6. C. 85-95.

38. Перцов Н.В. Инварианты в русском словоизменении. Москва : Языки русской культуры, 2001. С. 88-101, 221-244.

39. Пешковский А.М. Русский синтаксис в научном освещении Звегинцева В.А. История языкознания ХІХ-XX веков. Москва, 1965. Ч. $2.496 \mathrm{c}$.

40. Русанівський В. М. Структура українського дієслова. Київ : Наукова думка, 1971. 313 с.

41. Русская граматика / Акад. наук СССР, Ин-т рус. яз. ; редкол. : докт. филол. наук Н.Ю. Шведова (гл. ред.) и др. Москва : Наука, 1980. T. $1.788 \mathrm{c}$.

42. Сергиевская Л.А. Императивные предложения со значением совместного действия в современном русском языке : автореф. дисс. ... канд. филол. наук : 10.02.01. Москва, 1982. 20 с.

43. Серль Дж.Р. Классификация иллокутивных актов. Новое в зарубежной лингвистике. Москва : Прогресс, 1986. Вып. 17. 424 с.

44. Скаб М.С. Граматика апеляції в українській мові. Чернівці : Мicто, 2002. $272 \mathrm{c.}$

45. Тошович Б. Экспрессивный синтаксис глагола. Москва : Языки славянской культуры, 2006. 560 с.

46. Харченко С.В. Семантико-синтаксична та комунікативна структура речень спонукальної модальності : автореф. дис. ... канд. філол. наук : 10.02.01. Київ, 2001. 21 с. 
47. Храковский В.С., Володин А.П. Семантика и типология императива. Русский императив. Москва : Едиториал УРСС, 2002. $272 \mathrm{c}$.

48. Храковский В.С. Императив и залог (к вопросу о взаимодействии граммем разных грамматических категорий Функциональнотипологические аспекты анализа императива. Москва, 1990. Ч. 1 : Грамматика и типология повелительных предложений / под ред. Л.А. Бирюлина, В.С. Храковского. 152 с.

49. Храковский В.С. Императив и залог (к вопросу о взаимодействии граммем разных грамматических категорий Функциональнотипологические аспекты анализа императива. Москва, 1990. Ч. 1 : Грамматика и типология повелительных предложений / под ред. Л.А. Бирюлина, В.С. Храковского. 152 с.

50. Церенчимедийн С. Речевые акты побуждения, их типы и способы выражения в русском языке : дисс. ... докт. филол. наук : 10.02.01. Москва, 1993. 246 с.

51. Шатілова О.С. Динаміка структури та семантики спонукальних конструкцій в українських публіцистичних текстах початку XXI століття : автореф. дис. ... канд. філол. наук : 10.02.01. Донецьк, 2013. $20 \mathrm{c}$.

52. Шведова Н.Ю. О долженствовательном наклонении. Синтаксис и норма : сборник статей / отв. ред. докт. филол. наук Г.А. Золотова. Москва : Наука, 1974. С. 107-121.

53. Штелинг Д.А. О грамматическом статусе повелительного наклонения. Известия АН СССР. Серия литературы и языка. 1982. T. 41. № 3. C. 266-271.

54. Якобсон Р.О. Шифтеры, глагольные категории и русский глагол/ пер. с англ. А.К. Жолковского. Принципы типологического анализа языков различного строя. Москва : Наука, 1972. С. 95-113.

55.Ebeling C.L. On the verbal predicate in Russian. The Hague, 1956. $212 \mathrm{p}$.

56. Davies E. The English Imperative. London et al. : Croom Helm, 1986. P. 39-40.

57. Searle J.R. A taxonomy of illocutionary acts. Expression and Meaning. Cambridge etc. : Cambridge University Press, 1979. 187 c.

Information about the author: Bortun K. O., $\mathrm{PhD}$ in Philology, National Technical University of Ukraine "Igor Sikorsky Kyiv Polytechnic Institute" 37, Peremohy avenue, Kyiv, 03056, Ukraine 